\title{
A study of wave disturbances over the China continent and the East China Sea in winter 1968.*
}

\author{
By M. Yoshizaki** \\ Geophysical Institute, Tokyo University \\ (Manuscript received 25, July 1973, in revised form 22, April 1974)
}

\begin{abstract}
The characteristic features of disturbances during the period of January, February and March in 1968 over the China continent and the East China Sea are studied in connection with the Air Mass Transformation Experiment (AMTEX) which is planned as one of the GARP subprogram.

In January, wave disturbances with 6 7-day period which correspond to long waves in middle latitudes are found over the China continent and the East China Sea. In middle January, short waves of 2 3-day period with upper troughs exist and the time-spectra of the mixing ratio of water vapour show large power density in this short period range.

In March, the activity of wave disturbances is weak but the East China Sea area is affected by the passage of long waves whose center is located at higher latitudes.
\end{abstract}

\section{Introduction}

Air Mass Transformation Experiment (AMTEX) is planned as an experiment among the GARP subprogram to clarify the energy transformation processes over the East China Sea. Preliminary studies have been done by Ninomiya $(1972,1973)$ and Nitta, Nanbu and Yoshizaki (1973). Ninomiya (1972) examined heat and moisture budgets in February 1968. Nitta et al. (1973) investigated wave disturbances during the same period and obtained two types of wave disturbances; the one is a long wave with $4 \sim 5$-day period and the other is a medium-scale disturbance with 1.5 2-day period. Both disturbances have the vertical structure of baroclinic unstable waves.

This study is an extension of the observational study of Nitta et al. (1973). Wave disturbances during three months from January to March in 1968 are examined and differences of characteristic features of disturbances between three months are discussed.

\section{General features of wave disturbances during three months.}

The data and the method of analysis used in this study are the same as those of Nitta et al.

* Division of Meteorology, Contribution No. 216

** Present Adress: Ocean Research Institute University of Tokyo

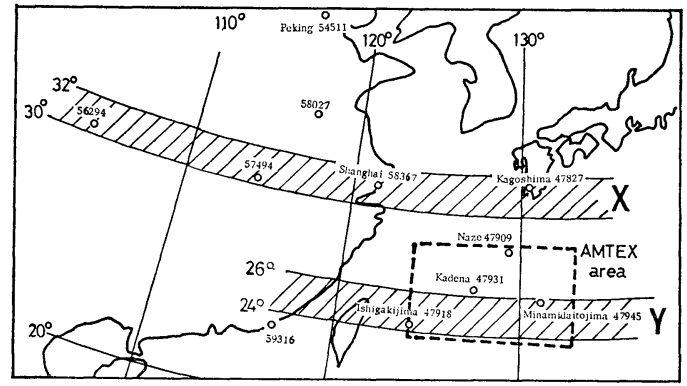

Fig. 1. Upper air observation stations over the China continent and the East China Sea. The zonal belts denoted by $\mathrm{X}$ and $\mathrm{Y}$ are along $30^{\circ}-32^{\circ} \mathrm{N}$ and $24^{\circ}-26^{\circ} \mathrm{N}$.

(1973) except the analyzed period. Fig. 1 shows the locations of upper air observation stations. Two belts denoted by $\mathrm{X}$ and $\mathrm{Y}$ are zonal belts of $30^{\circ} \sim 32^{\circ} \mathrm{N}$ and $24^{\circ} \sim 26^{\circ} \mathrm{N}$ used for analysis.

Fig. 2 illustrates the longitude-time cross section of wind at $850 \mathrm{mb}$ along the belt $\mathrm{Y}$ from January to March. Areas of southerly winds are shaded. In the eastern part of the China continent in January, short period disturbances about $2 \sim 3$ days appear and propagate eastward. However, over the East China Sea $\left(120^{\circ} \mathrm{E}-130^{\circ} \mathrm{E}\right)$ long period disturbances about 6 7-day period are dominant (Fig. 2 (a)). Early in February propagating disturbances are not clearly found over the East China Sea. But Nitta et al. (1973) found 2-day period disturbances during this period and 


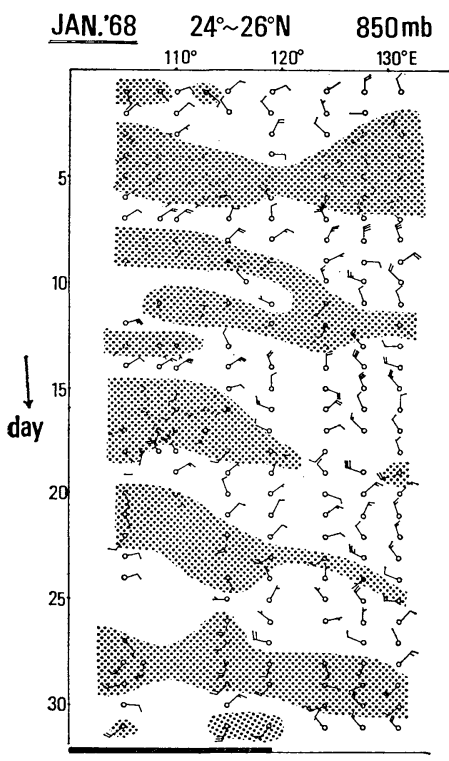

(a)

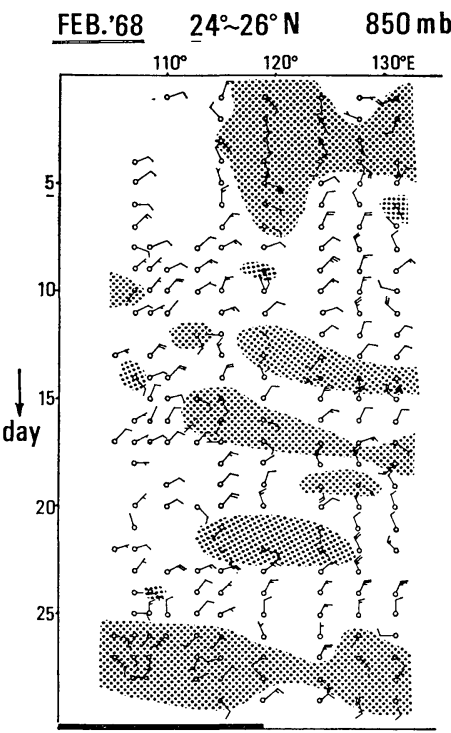

(b)

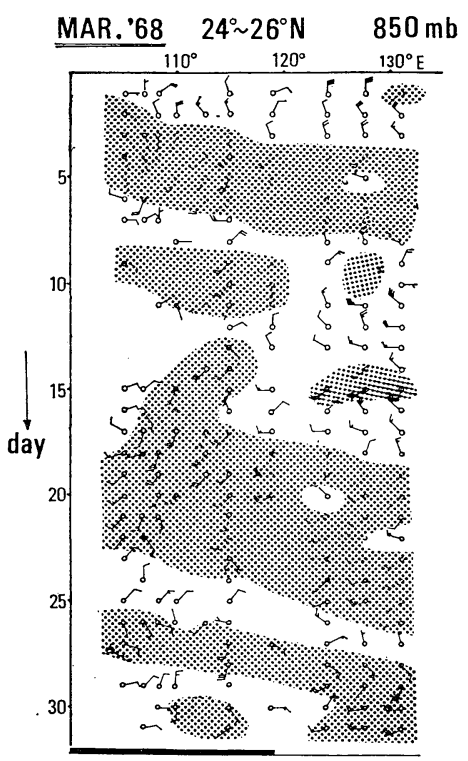

(c)

Fig. 2. The longitude-time cross section of wind at $850 \mathrm{mb}$ along the latitude between $24^{\circ}-26^{\circ} \mathrm{N}$ (Belt Y) from January to March. Areas of southerly wind are shaded.

Ninomiya (1973) also showed the existence of these short period disturbances by the radar echo analysis. From mid-February to late February, 4 5-day period disturbances are observed over the East China Sea. In March there are propagating disturbances, but the regular periodicity is not found.

\section{Wave disturbances in January}

\section{3-1. Wave disturbances of 6 7-day period.}

(a) Power spectra of wind and temperature

Figs. 3(a) and 3(b) illustrate power spectra of $\mathrm{V}$-component of wind and temperature along the belts $\mathrm{X}$ and $\mathrm{Y}$, respectively. There exist wave disturbances of $6 \sim 7$-day period with maximum amplitude near $850 \mathrm{mb}$ along both belts. The amplitude over the East China Sea is larger than that in the continent. Power spectral densities of $\mathrm{V}$ and $\mathrm{T}$ in the short period range less than 6 days are very small except Kagoshima (47827). Fig. 3(c) shows the power spectra of $\mathrm{V}$ and $\mathrm{T}$ at Peking located at about $40^{\circ} \mathrm{N}$. Wave disturbances of $6 \sim 7$-day period are dominant also at this higher latitude. In order to investigate the relation between wave disturbances of $6 \sim 7$-day period at Peking and those in the East China Sea, we compute cross spectra of $\mathrm{V}$ and $\mathrm{T}$ between two regions. The coherence between two regions is very high (more than 0.9). We consider that the wave disturbance of $6 \sim 7$-day period appearing over the East China Sea is the same as that at Peking and is a typical disturbance in mid-latitude in winter.

(b) Longitudinal scale and vertical structure

From horizontal phase differences of $\mathrm{V}$ between various stations and vertical phase differences at each station, we can estimate phase speed, horizontal scale and vertical structure of wave disturbances. Figs. 4(a) and 4(b) show the relation between phase difference $(\Delta \theta)$ and longitudinal seperation of stations $(\Delta \lambda)$ at $700 \mathrm{mb}$ along the belts $\mathrm{X}$ and $\mathrm{Y}$, respectively. It is concluded that these disturbances propagate eastward and wave length estimated from the inclination of the line is $6000 \sim 7000 \mathrm{~km}$ along both belts.

Fig. 5 shows the vertical structure of wave disturbances at Ishigakijima. We calculate the vertical phase differences of $\mathrm{V}, \mathrm{T}$ and $\mathrm{R}$ (mixing ratio of water vapour) on the reference to 850 $\mathrm{mb}$. The trough tilts westward with height, and warm and moist air lies to the east of the trough. Moist air is usually brought by the upward motion. The vertical structure of this wave disturbance is similar to that of baroclinic waves.

\section{3-2. Wave disturbances of 2 3-day period}

In the pervious sub-section we investigated the 

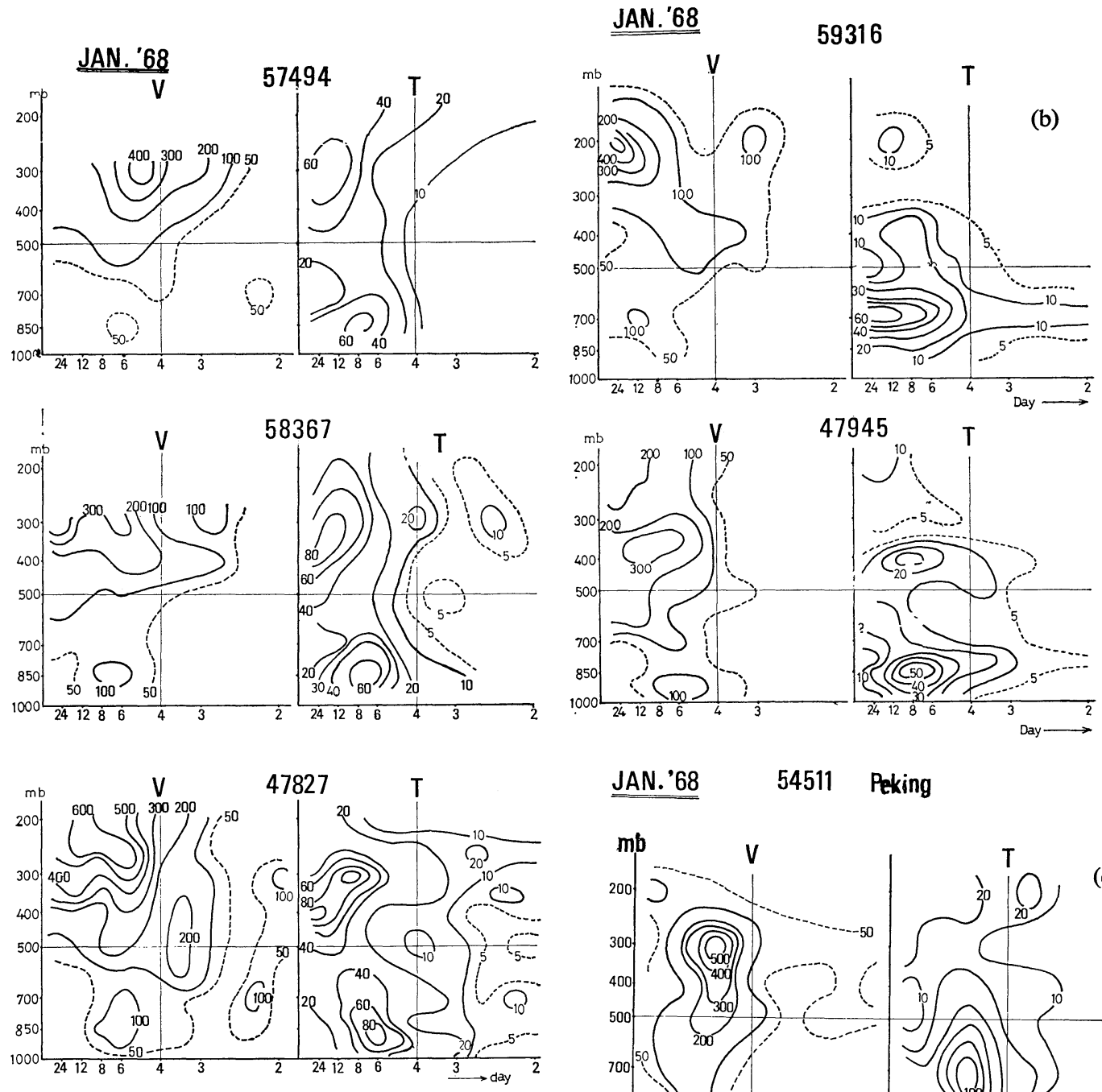

\section{JAN.'68 54511 Peking}

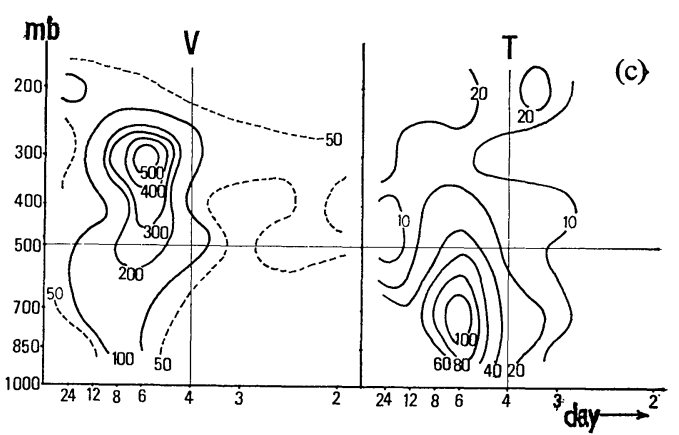

Fig. 3 (a). Power spectra of the V-component of wind and temperature along the belt $\mathrm{X}$ in January. The abscissa denotes the period (unit: day) and the ordinate the height. The units of isopleths are $(\mathrm{m} / \mathrm{sec} \text {. })^{2}$. day as for $\mathrm{V}$ and $\left({ }^{\circ} \mathrm{c}\right)^{2}$. day as for $\mathrm{T}$. The numbers in figures 57494,58367 and 47827 denote the observation points, Hankow, Shanghai and Kagoshima such as shown in Fig. 1.

(b). Same as (a) except along the belt Y. 59316 and 47945 denote Shantou and Minamidaitojima.

(c). Same as (a) except at Peking. 
(a)

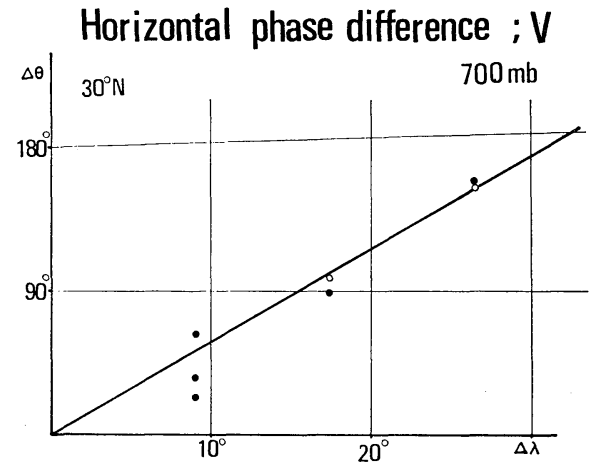

(b)

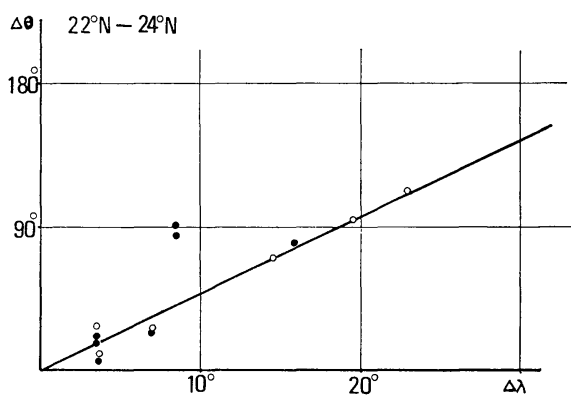

Fig. 4. The relation of the V-component of wind between phase defference $(\Delta \theta)$ and longitudinal seperation of stations $(\Delta \lambda)$ at $700 \mathrm{mb}$ along the belts $\mathrm{X}$ and $\mathrm{Y}$. wave disturbances of 6 7-day period, but we could not find any other remarkable peaks in the power spectra of $\mathrm{V}$ and $\mathrm{T}$ in the lower atmosphere. In AMTEX area, however, there exists a peak of short period near $700 \mathrm{mb}$ in the power spectra of $\mathbf{R}$.

Fig. 6 shows the power spectra of $V, T$ and $R$ at Naze. As a matter of course, a large power density exists in the 6 7-day period in all parameters, but it is noticed that a large power density exists near 3 days at $700 \mathrm{mb}$ in the power spectra of $\mathrm{R}$.

Fig. 7 shows the time series of wind, temperature and mixing ratio at Naze from 6 to 15 January. The circles shown at surface denote the cloud amount. Solid, dotted and chained lines denote isolines of temperature and mixing ratio, and the axes of troughs, respectively. During this period the troughs pass over with $2 \sim 3$-day period. It is found from the weather maps (not shown) that the upper troughs stretch from north to south and weathers over the AMTEX area change rapidly according as the troughs move. In case of January, $\mathrm{R}$ is more sensitive than $\mathrm{T}$ and $\mathrm{V}$ to the short period disturbances in the lower atmosphere as shown in Figs. 6 and 7.

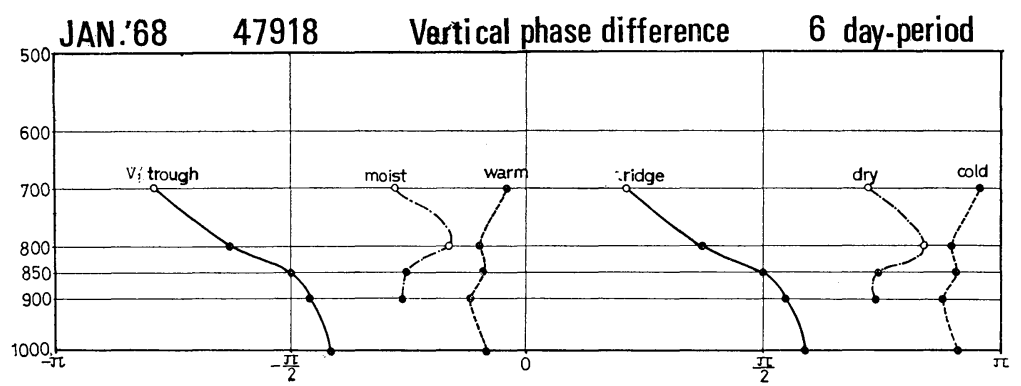

Fig. 5. Vortical structure of wave disturbances with 6 day-period at Ishigakijima.

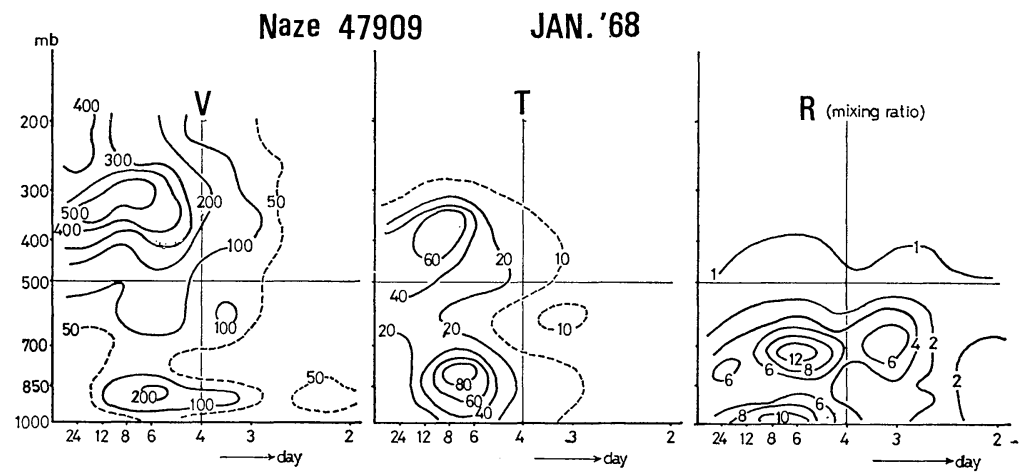

Fig. 6. Power spectra of $\mathrm{V}, \mathrm{T}$ and $\mathrm{R}$ at Naze in January. Units of the power spectra of $\mathrm{V}$ and $\mathrm{T}$ are the same as those in Fig. 3. 


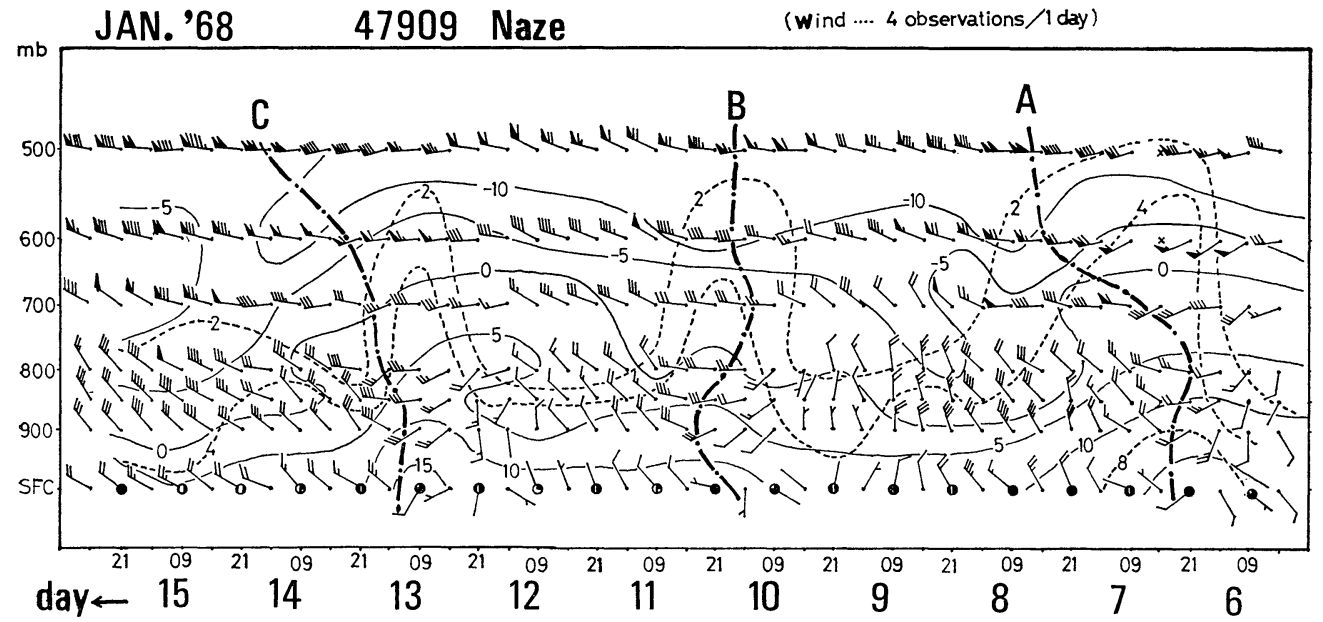

Fig. 7. The time section of wind at Naze from 6 to 15 January. The circles at surface denote the cloud amount. Solid, dotted and chained lines stand for temperature, the mixing ratio and the troughs.

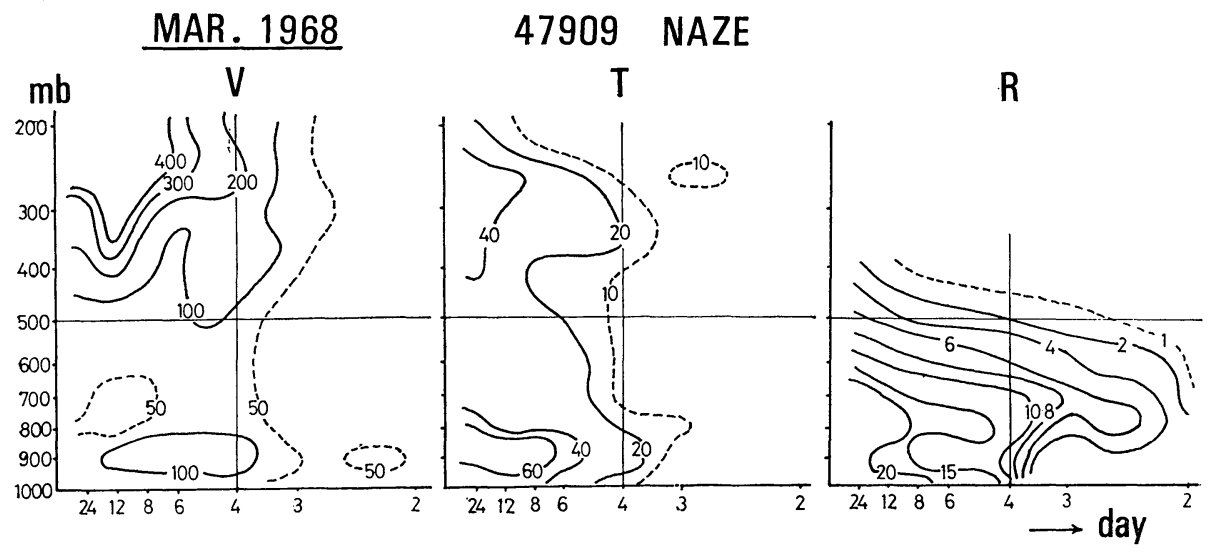

Fig. 8. The power spectra of $\mathrm{V}, \mathrm{T}$ and $\mathrm{R}$ at Naze in March. Units are the same as those in Fig. 6.

\section{Wave disturbances in March}

Wave disturbances in February have been already studied by Nitta et al. (1973). We shall then investigate wave disturbances in March. Fig. 8 shows the power spectra of $\mathrm{V}, \mathrm{T}$ and $\mathrm{R}$ at Naze. There exist large power densities in the spectra of $\mathrm{V}, \mathrm{T}$ and $\mathrm{R}$ in the longer period range more than 6 days. However, the period ranges of the large power densities in March are wider than those of the previous two months and the amplitude is smaller than the previous months. The results of the obscure peaks in the power spectra are consistent with those of the longitudetime section of the wind in Fig. 2(c).
Power densities of $\mathrm{V}$ (solid lines) and $\mathrm{T}$ (dashed lines) at $850 \mathrm{mb}$ at Kagoshima, Naze, Kadena and Ishigakijima are shown in Fig. 9. These stations lie on the line from northeast to southwest as shown in Fig. 1. There exist large power densities at the four stations in the long period range especially in the V-spectra and the amplitude in this period range becomes large with increasing latitude. We conclude that the wave disturbance of 6 8-day period in March is the same as that found in January and its center lies to the north of the East China Sea.

Fig. 10 shows the power spectra of $\mathrm{V}$ and $\mathrm{T}$ at $850 \mathrm{mb}$ at Ishigakijima for each month. The amplitude in the longer period range more than 

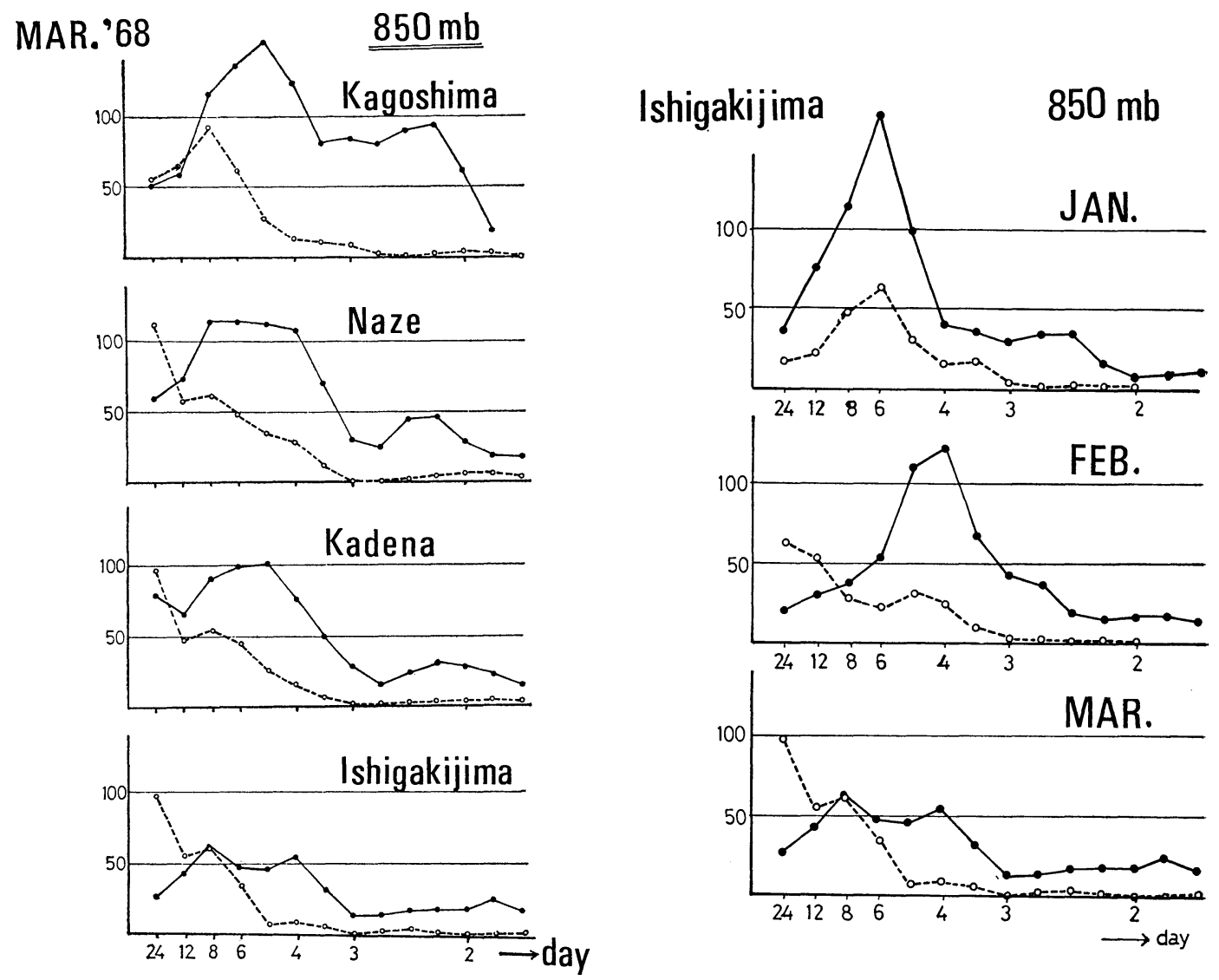

Fig. 10. The intensity of $\mathrm{V}$ and $\mathrm{T}$ at Ishigakijima from January to March. Solid and broken lines denote $\mathrm{V}$ and $\mathrm{T}$, respectively. Units are the same as those in Fig. 3.

Table 1. Temperature difference between Kagoshima and Naze. $T=\bar{T}($ Kagosima $)-\bar{T}($ Naze $)$

\begin{tabular}{|c|c|c|c|c|}
\hline$T$ & 1 Jan. $\frac{(\mathrm{a})}{1967} 20 \mathrm{Jan}$. & 21 Jan. $\frac{(b)}{1968}$ & 11 Feb. $\frac{(c)}{1968} 29 \mathrm{Feb}$ & $1 \operatorname{Mar} \frac{(\mathrm{d})}{1968}$ Mar. \\
\hline $400 \mathrm{mb}$ & -6.2 & -8.4 & -4.1 & -3.5 \\
\hline 500 & -5.6 & -4.6 & -4.4 & -2.8 \\
\hline 600 & -5.5 & -3.9 & -4.7 & -2.7 \\
\hline 700 & -5.1 & -4.2 & -4.5 & -3.3 \\
\hline 800 & -3.7 & -3.1 & -2.2 & -4.0 \\
\hline 900 & -4.5 & -6.4 & -4.5 & -2.5 \\
\hline SFC & -5.8 & -6.8 & -6.0 & -4.1 \\
\hline
\end{tabular}


4 days in March is weaker than that in the previous two months. The weakness of the amplitude of the long waves in March over the East China Sea may be caused by the weak baroclinicity as shown in Table 1 .

\section{Conclusions and remarks}

Wave disturbances in the China continent and the East China Sea during the period from January to March 1968 are examined. In January the long wave disturbances of 6 7-day period and $6000 \sim 7000 \mathrm{~km}$ wavelength are dominant in the East China Sea and are considered to be the usual baroclinic unstable waves in mid-latitudes in winter. In particular period short period disturbances of 2 3-day period are found especially in R-spectra in the East China Sea. In March the periodicity of wave disturbances is weak as compared with that in the January and February. There exist spectral peaks near 6 8-day period in the Vcomponent in the East China Sea but these peaks may be caused by the passage of the long waves whose center is located at the higher latitudes to the north of the East China Sea.

Differences of the characteristic features of long waves between February and the other two months are;

(1) The preferred period of the long waves is $4 \sim 5$ days in February but $6 \sim 8$ days in January and March.

(2) Short period disturbances of 2 3-day period are observed in the lower atmosphere in January and February. In January they are affected by the upper troughs which stretch from north to south, but the short period disturbances in February are limited in the East China Sea.

\section{Acknowledgements}

The author wishes to express his thanks to Prof. K. Gambo and Prof. T. Matsuno, who gave him many effective suggestions and encouragements throughout his work. The author is also indebted to Dr. Tsuyoshi Nitta for his guidance. Thanks are extended to Mrs. M. Miyazawa for typing of the draft.

\section{Reference}

Joint Organizing Committee, GARP, 1973:

Air Mass Transformation Experiment. GARP Publication Series, 13.

Ninomiya, K., 1972: Heat and water-vapour budget over the East China Sea in the winter season. $J$. Meteor. Soc. Japan, 50, 1-17.

- 1973: Variation in the heat energy budget over the East China Sea associated with the passage of wave cyclones in February 1968. J. Meteor. Soc. Japan, 51, 435-449.

Nitta, Tsu., M. Nanbu and M. Yoshizaki, 1973: Wave disturbances over the China continent and the Eastern China Sea in February 1968. J. Meteor. Soc. Japan, 51, 11-28.

\title{
1968 年冬期, 中国大陸および東シナ海でみられる波動じょう乱の解析
}

\author{
吉 崎 正 憲 \\ 東京大学理学部
}

GARP の副プログラムとして計画されている AMTEX に関連して, 1968 年 1 月から 3 月までの期間に中国大陸 和よび東シナ海にあらわれる波動じょう乱を調べた。

1 月には中緯度地方によく見られる 6 ～ 7 日周期の長波が中国大陸和よび東シナ海に卓越していた。限られた期間 飞上層のトラフに伴なった $2 \sim 3$ 日周期の短周期の波が見られ, パワースペクトルでは, 水蒸気の変動によくあらわ れた.

また 3 月には，6〜日周期の波がみられたが，1月，2月に比べて弱く，ピークの周期もはっきりしない. 